\title{
Immunosenescence is both functional/adaptive and dysfunctional/maladaptive
}

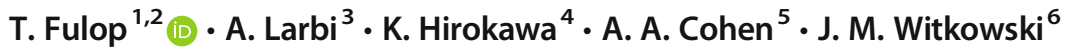

Received: 1 June 2020 / Accepted: 24 August 2020 / Published online: 15 September 2020

(C) Springer-Verlag GmbH Germany, part of Springer Nature 2020

\begin{abstract}
Alterations in the immune system with aging are considered to underlie many age-related diseases. However, many elderly individuals remain healthy until even a very advanced age. There is also an increase in numbers of centenarians and their apparent fitness. We should therefore change our unilaterally detrimental consideration of age-related immune changes. Recent data taking into consideration the immunobiography concept may allow for meaningful distinctions among various aging trajectories. This implies that the aging immune system has a homeodynamic characteristic balanced between adaptive and maladaptive aspects. The survival and health of an individual depends from the equilibrium of this balance. In this article, we highlight which parts of the aging of the immune system may be considered adaptive in contrast to those that may be maladaptive.
\end{abstract}

Keywords Immunosenescence - Inflammaging · Adaptation - Maladaptation · Trained immunity · Centenarians · Immunosuppressive mechanisms

\section{Introduction}

Due to the current COVID-19 pandemic, there is much interest in the immune system of older individuals, who are at highest risk of severe disease and death [1-5]. It seems to be common knowledge that infections and diseases are increased in the elderly and may be considered associated with the aging process itself [6-9]. In the meantime, there is an unprecedented increase both in life expectancy and in the number of centenarians and semi-supercentenarians (several "blue zones"

This article is a contribution to the special issue on: Immunosenescence: New Biomedical Perspectives - Guest Editors: Claudio Franceschi, Aurelia Santoro, and Miriam Capri

\section{T. Fulop}

Tamas.Fulop@Usherbrooke.ca

1 Department of Geriatrics, Faculty of Medicine, Research Center on Aging, University of Sherbrooke, Sherbrooke, QC J1K 2R1, Canada

2 Research Center on Aging, Faculty of Medicine and Health Sciences, University of Sherbrooke, 3001, 12th Avenue North,

Sherbrooke, Quebec J1H 5N4, Canada

3 Biology of Aging Program and Immunomonitoring Platform, Singapore Immunology Network (SIgN), Agency for Science Technology and Research (A*STAR), Immunos Building, Biopolis, Singapore 138648, Singapore where these oldest old individuals are "enriched" compared with the general population exist on earth) $[10,11]$. Many changes have been described in the innate and adaptive immune systems with aging [12-20]. These contentions seem to represent completely contradictory trends which may be difficult to reconcile. Interestingly, two decades ago a common denominator of aging and age-related diseases called inflammaging was described by Franceschi et al. [9, 21-23], a concept that was largely based on the previously described age-related immune changes called as immunosenescence

4 Institute of Health and Life Science, Tokyo and Nito-memory Nakanosogo Hospital, Department of Pathology, Tokyo Med. Dent. University, Tokyo, Japan

5 Department of Family Medicine, Faculty of Medicine, Research Center on Aging, University of Sherbrooke, Sherbrooke, QC J1K 2R1, Canada

6 Department of Pathophysiology, Medical University of Gdansk, Gdansk, Poland 
$[24,25]$. As a corollary, this became for geroscience and the nine hallmarks of aging one of the basic underlying mechanisms of aging designated as "intercellular communication" [26-28]. However, a new appreciation of the data found in older adults suggests that not all changes in the immune system generally considered detrimental are actually harmful, and concomitantly the immune system of the elderly is able to perform better than it was previously suspected when adequately challenged $[29,30]$.

As mentioned, the common paradigm is that age-related diseases (ARDs) and the decreased vaccine response are somehow linked to immune alterations with aging, commonly called immunosenescence $[16,20]$. However, several recent observations challenge this idea. First, the elderly are in fact able to sustain an adequate vaccine response compared with young subjects [30]. Second, for semi-supercentenarians the most important survival factor was proposed to be inflammation [31-33]. Third, the immune checkpoint inhibitors are as efficient in elderly as in young $[34,35]$. Lastly, most infections are not fatal in the elderly, including COVID-19, and not all older adults suffer from numerous age-related diseases [36, 37].

Therefore, it could be conceptualized that the age-related immune changes may be a mix of adaptation/resilience and maladaptation/allostatic load, which are closely related to what was called the immunobiography or immunoadaptation, in line with the well-known physiological concepts hormesis and homeodynamics [25, 38-40]. In this article, we propose a framework to understand adaptation and maladaptation of the immune system and their consequences for elderly. Thus, we will describe a holistic conceptualization of the immune system changes during aging, called the "adaptage theory."

\section{Aging-associated changes in the immune system}

The main role of the immune response is the protection of the organism from all external and internal challenges in the form of pathogenic microorganisms as well as transformed (neoplastic) or damaged (injured) cells [7, 23]. The immune system is fully equipped to perform this complex task. However, many reports state that with aging there is not a single part of this response which would not undergo changes, and these changes were uniformly conceptualized as being only "bad," deteriorative changes, and their consequences could be only detrimental for elderly [41-43]. This notion generated the concept of removing the problem by the rejuvenation of the immune system of the aged individuals to the level of young subjects $[44,45]$, however in the physiological environment of an otherwise old organism.

Usually, the aging-associated changes in the immune system are described separately for its innate and adaptive compartments. Here we will try to describe the unified concept of these age-related changes. When we consider aging, we consider time. So, the immune system today is not the same as yesterday, neither in young nor in elderly persons. This means that at every moment challenges are arising in our external and internal environment which should be dealt with by the immune system [38] and that these challenges build on the previous state. This implies that every event occurring during life will consequently change or sculpt the immune response [25].

So, during life, we have many aggressions which can be halted by the innate immune system alone, or if they are more serious, they will need the involvement of the adaptive immune system $[46,47]$. Thus, in any case, the first encounter of an external or internal pathogen is with the cells of innate immune system [48]. This system is fully equipped to deal with all aggressors in a very fast time frame starting from minutes to days. This system is composed of neutrophils, monocytes/macrophages, dendritic cells (DC) and NK cells, and numerous soluble mediators secreted by these cells, including cytokines and chemokines [49]. By itself, this system is powerful enough to clear an aggression without harm [50, 51] but also in special circumstances to turn against its own by sustaining inflammation, over time leading to chronic inflammatory diseases [52-54]. Among these are, for example, rheumatoid diseases, atherosclerosis, cancer, or asthma, the precursory stages of which may be arising very early in life [55, 56].

Acute inflammation is meant to eliminate everything which is harmful for the organism and ends with a (near) complete return to the original state. However, if the aggression is chronic, or if the innate immune system is not set back because the regulatory mechanisms are overwhelmed, the inflammatory process can become chronic and potentially harmful. When we think about a chronic process, we suppose that time plays a role; thus, aging (occurring with time) is a relevant factor [57]. This means that all these pathologies are considered ARDs. Nevertheless, we should mention that the chronic nature of such stimulation has already somehow elucidated the occurrence (explained the beginnings) of these diseases early in life [57].

The concept of trained innate immune memory sheds some light how the innate immune system may orchestrate the eventual alertness or chronicity of the innate immune response. At each aggression, innate immune cells such as monocytes are activated [58-62]. "Trained" at each occasion by intracellular immunometabolic changes/reprogramming as well as by subsequent epigenetic imprint, these cells will increase their inflammatory response [63-65]. However, this process may take two different paths. One path is the controlled, wellorchestrated innate immune memory, which helps to resolve aggressions rapidly and stop the inflammatory process, but nonetheless remains at a higher activation/readiness state 
[58-62]. The other pathway is less controlled, which can lead to what has been called "immune paralysis" [66]. Not only will the response not be adequate, but these cells are already overstimulated, so a new stimulus may not trigger an efficient response and the functionality of the innate immune cells will decrease when it should increase. This has been shown also for some specific phagocytic cells' functions with aging [67]. A basal state of activation of the innate cells was demonstrated with aging, which may lead to a preparedness and readiness of the system [68-71]. This may help the innate immune system to be reactive more quickly and at a higher level. Interestingly, many tissue-resident and blood-born innate immune cells, including neutrophils and microglia, display hyperactivation phenotypes with aging [72, 73]. However, it was also shown that this may lead to a relative immune paralysis state resulting in the blunting of the innate cells functionality when specifically challenged. It should be mentioned that this does not mean that these phagocytic cells may not enhance their functions, but not in all elderly and not to the level as would be expected in case of young. This is corroborated by the findings that most elderly subjects may efficiently clear an infection, such as influenza or even SARS-CoV-2 [14, 16, 37, 74]. Certainly, this happens in fewer cases than in young subjects, but it is not impossible. Thus, this is a perfect example of the adaptation/maladaptation concept of the aged immune system.

Moreover, the innate immune response can also determine how the adaptive immune system will react $[75,76]$. Cells have evolved which seem to be intermediate between the innate and the adaptive immune system and may react faster than standard adaptive immune system but keep its characteristics [76-78]. These innate lymphoid cells (ILC) are broadly classified into three main subsets: ILC1 (IFN- $\gamma$ producing), ILC2 (IL-4, IL-5, and IL-13 producing), and ILC3 (IL-17 or IL-22 producing or both) $[79,80]$. ILCs are either present in the tissues or in the circulation. They can rapidly react to microbial and cytokine signals. They also rapidly induce the CXCL13 chemokine, which is the ligand of CXCR5 playing a role in the tissue accumulation of these ILCs [81, 82]. By their rapid response, these cells also contribute to the eradication of the microbes constantly invading the human organism and permanently threatening its overall health.

The innate-like $\mathrm{T}$ cells comprise the cells displaying a $\gamma \delta \mathrm{TCR}$, mucosa-associated invariant T (MAIT), iNKT (Invariant Natural Killer T), GEMT (germline-encoded mycolyl lipid-reactive), and innate-like B cells [83]. These cells recognize foreign/self-lipid presented by nonclassical MHC molecules, such as CD1d, MR1, and CD1a [84]. They are activated during the early stages of bacterial infection and act as a bridge between the innate and adaptive immune systems. Unlike their conventional counterparts, innate $\mathrm{T}$ cells rapidly recognize foreign pathogen signals and manifest immediate effector functions after activation [85]. These innate $\mathrm{T}$ cells are implicated in immune responses to viral infections such as CMV, are able to recognize a broad range of cancer cells, and react to stress-induced molecules, such as MHC class I-related chains A and B (MICA and MICB) that are expressed on virus-infected cells and also participate in the general antimicrobial defense [86-88]. The nature of the antigens recognized by innate $\mathrm{T}$ cells is also diverse and broadly non-overlapping, involving metabolites, bacterial products, and lipids. iNKT cells have been principally shown to respond to glycolipids, $\gamma \delta \mathrm{T}$ cells are potently activated by (E)-4-hydroxy-3-methyl-but-2-enylpyrophosphate (HMBPP) [89], and MAIT cells can be activated by riboflavin metabolitesreduced 6-hydroxy methyl-8- $\delta$-ribitylumazine (rRL-6$\mathrm{CH} 2 \mathrm{OH}$ ), as well as folic acid metabolite, 6formylpterin(6FP) [90]. So, they have some characteristics of the innate immunity such as rapid effector functions but also adaptive immunity because of the rearrangement of their TCR and thymic selection. This allows innate T cells to perform effector immune responses much earlier than conventional T cells and act as an additional "bridge" between innate and adaptive immune responses. Studies demonstrate that unconventional $\mathrm{T}$ cells do indeed contribute to the ability of host organisms to clear and control certain bacterial infections. These cells are able to efficiently travel to the sites of inflammation and initiate rapid responses by means of cytokine production and cytotoxic activities.

In the description of immune changes with aging, there are a few places for these essential cells. Larbi and his group devoted a lot of work to understand how these cells work during aging $[91,92]$. They have shown that $\mathrm{V} \delta 2+\mathrm{T}$ cells composition and functionality are not altered in older adults. They have further shown that peripheral V $\delta 2+$ phenotype, functional capacity (cytokines, cytotoxicity, proliferation), and gene expression profile are specific to this subset when compared against all other $\alpha \beta$ and $\gamma \delta$ T cells in aging. Also, hallmarks of senescence including telomere length, epigenetic profile, and DNA damage response of $\mathrm{V} \delta 2+$ differ from all other $\alpha \beta$ and $\gamma \delta$ T cells. Finally, they have shown that V $\delta 2+$ are resistant to cellular aging due to their unique epigenetic and transcriptomic signatures. These findings constitute another type of adaptation in view to compensate/complement the changes observed in adaptative $\mathrm{T}$ cells during aging. Future work should unravel whether this potential of being resilient to stressors in $\mathrm{V} \delta 2+$ could be promoted in other cell type and consequently exploited to lead to better response to infections and in the field of cancer immunotherapy or designing a vaccine utilizing $\mathrm{V} \delta 2+$ properties for the elderly.

Group 2 ILC (ILC2) respond to the alarmin cytokine IL-33 and are potent producers of IL- 5 and IL-13 as well as a variety of other effector molecules in vitro and in vivo [93]. Tissueresident ILC2 are implicated in tissue repair, tissue remodeling, and metabolic homeostasis [94]. Recently, it was shown in the choroid plexus of the brain that ILC2 in the aged brain 
are long-lived and capable of reversibly switching between cell cycle dormancy and proliferation [95]. They are relatively resistant to cellular senescence and exhaustion under replication stress, leading to enhanced self-renewal capability. When activated in vitro and transferred intracerebroventricularly, they revitalized the aged brains and enhanced cognitive function of aged mice. These results suggest that aging may expand a unique population of brain-resident ILC2 with enhanced cellular fitness and potent neuroprotective capability, by decreasing neuroinflammation, cellular senescence, and exhaustion and moreover capable of self-renewing. It is still unclear whether similar ILC2 cells may be found elsewhere in aging organism, but this is another cell type which may resist the "detrimental" effect of aging and show adaptative traits even if is occurring locally.

The subsets of memory or memory-like $\mathrm{T}$ and $\mathrm{B}$ cells with innate-like properties have been observed to accumulate with aging [42, 96-100]. The increased numbers and activity of certain innate or innate-like immune cell subsets with aging might be considered host responses to compensate for the drastic decline in adaptive immune cell development and function [95]. These cells mirror the findings in V $\delta 2+$ $\mathrm{T}$ cells as described above and show the plasticity and adaptability of the innate and innate-like cells with aging, probably maintaining some physiologically important functions when the other part of the system is fainting [91]. Thus, we can say that the effects of aging on the immune system are much more complicated than a commonly preached generalized decline in immune cell development, phenotype, and function.

Once an aggression occurs and the innate response is inefficient or insufficient to clear it, the innate system should drive the adaptive immune system to react $[75,76]$. This is carried out by coordinated and efficient actions by the cells and the soluble mediators of the innate immune system. The antigens should be efficiently presented, and the mediators should prime the adaptive immunity. It has often been stated that antigen presentation is altered with aging; however, this is still controversial and probably depends on the strength of the innate stimulation [101-107]. Dendritic cells (DCs) are one type of innate immune cell known for antigen presentation, being key components linking innate and adaptive immunity through priming of naïve $\mathrm{T}$ cells and shaping adaptive $\mathrm{T}$ cell responses $[108,109]$. There are two major DC subsets in human peripheral blood: conventional DCs (cDCs) and plasmacytoid DCs (pDCs). These DC subsets recognize different pathogen-associated molecular patterns by expressing distinct repertoires of Toll-like receptors (TLRs) and other receptors $[110,111]$. Engagement of specific DC subset TLRs in turn triggers distinct immune response pathways. For example, pDCs produce a large amount of interferon alpha (IFN-a) in response to virus infection [112]. As mentioned, age effect studies of human DCs have been controversial [107]. While some studies demonstrated agedependent declines, others have shown no difference in the number of circulating DCs [113, 114]. Several studies have also indicated age-related functional changes in DCs, such as impaired expression of TLRs [115]; decreased production of cytokines, chemokines, and IFN-a after TLR stimulation [112-116]; and increased responses to self-antigen [117]. An earlier study has shown that the B cell and monocyte antigen presentation in the frame of MHC did not change with age. However, what was interesting in the data reported in one study is that among the 11 elderly even if the monocyte antigen presentation was homogenously maintained, there were 4 elderly with less BCR antigen presentation [106]. Even if most of the results suggest a change in antigen presentation, the various steps leading to it are differentially affected by age from the number of DCs through the immunoproteasome processing and the final MHC dependent presentation like in B cells. Interestingly, almost a quarter century ago, one of us (JMW) had demonstrated that the level of expression of MHC class I (H-2) molecules on spleen T cells of old mice is higher than on the surface of young splenic T cells; this effect was concomitant with the significant (homeostatic?) decrease of the level of transporter of antigenic peptides (TAP)- 1 in the same cells [118]. These observations were later supported by Assounga et al. [119]. Contrarily, expression of MHC Class II on macrophages derived from old mice was reported to be decreased compared with young animals [120]. These data even if contradictory may also illustrate that in the immune system, the changes are not uniform, and the system is self-adapted to compensate eventual failure of some part of the whole system. However, other non-antigen processing and presentation functions of APC, such as ability to become activated, costimulation, or cytokine/chemokine production, may play a role in the difficulties of the immune response to progress to the adaptive immune response [121]. More human studies are needed to clearly elucidate which processes are conserved and which are not in the antigen presentation process.

However, once the innate immune response is able to present the antigens, the adaptive immune response takes over with B and T lymphocytes' activation [75]. These main cell types executing the adaptive immune response have many different subpopulations [122]. This part of the immune system has been extensively studied in human aging [123-126]. There is a very broad consensus considering the adaptive immune system as the "devil" which is responsible for all the misfortunes of the immune system with age $[25,28]$. The most important changes are the decrease in the naïve immune cell compartment of the $\mathrm{CD} 4^{+}$and $\mathrm{CD} 8^{+} \mathrm{T}$ lymphocytes, however being more important in the latter $[12,16,96,97]$. Concomitantly, the TCR repertoire variability is also drastically decreased [127, 128]. In contrast, there is a concomitant increase in memory $\mathrm{T}$ and $\mathrm{B}$ cells which represent the 
subpopulation which already encountered antigens [129-131]. This quickens the adaptive response to cognate antigens, which is evolutionarily beneficial for the survival of an (older) individual, provided he/she stays in the general area where they spent their childhood and where meeting new, previously unknown pathogens is normally infrequent. The contrary would be quite strange if we consider from an evolutionary perspective that the immune system should react to all internal and external stimulation. This state of the adaptive immune system only reflects what we called earlier as immunobiography or immune history $[38,132]$. So, in this case, it should be considered neither bad nor good; it reflects only the reality of the role of the immune system. This is simply a life-long adaptation to life.

Certainly, the decrease of naïve cells in the elderly may not be advantageous for the survival of the individual when an encounter occurs with a completely new antigen such as the SARS-CoV-2 causing current (2020) pandemics of COVID19 [15]. As we already know, these individuals may die in proportions significantly higher than young COVID-19 patients $[1,2]$. The cause of this decrease of naïve $T$ cells is the involution of the thymus which starts early in life [13]. This also should have some adaptative reasons in the life of an individual. The maintenance of such an organ (with one of the highest proportions of concurrently dividing cells) is very costly in terms of metabolic energy; so, as most of the naïve $\mathrm{T}$ cells have been generated early in life, there is no need for its full function later in life. Also, if it is maintained, some errors in the regulatory mechanisms may occur with time, and some diseases such as autoimmune disease may increase. On the other hand, it should be stated that once more nature has foreseen a compensatory mechanism for lack of naïve $\mathrm{T}$ cells of thymic origin, which is their homeostatic proliferation in the periphery [133]. There is an unsettled debate among researchers as to whether this phenomenon fully replaces the lost TCR repertoire expressed by the thymus-generated naïve $\mathrm{T}$ cells. However, long survival of centenarians demonstrates that it should be an efficient compensatory mechanism. It is of note that many nonagenarians and centenarians recovered form COVID-19 despite the apparent lack of naïve $\mathrm{T}$ cells [134].

The increase of the memory (mainly $\mathrm{CD} 8^{+}$) $\mathrm{T}$ cells is also considered quite damaging for old individuals $[135,136]$. The reason is that their numerous proliferation cycles have led to what is called a senescent state or senescence [137-139]. This senescent state precludes their capacity to proliferate, mainly due to decreased CD28 expression resulting in slower and weaker activation during a known antigenic encounter, leading to decreased protection $[18,140]$. In the meantime, senescent $\mathrm{T}$ cells, analogously to other senescent cells arising with age in the body, produce large amounts of proinflammatory cytokines (a phenomenon called senescence-associated secretory phenotype, SASP) as stated by the inflammaging characteristics of the human immune system [141, 142]. This could substantially impede the response to recall antigens in specific cases, but in the meantime, the clinical and experimental evidence both point to the fact that even in the elderly, this part of the adaptive immune system may function efficiently. In the meantime, these cells are also able to contribute to the maintenance of innate immune preparedness. The SASP phenotype elicits an autocrine role on senescent cells, but it is also involved in the recruitment of immune cells, such as macrophages, neutrophils, and natural killer (NK) cells in order to eliminate the senescent cells themselves [143]. Concomitantly, upon accumulation of senescent cells, the production of cytokines is enhanced, along with the recruitment of immune cells, jointly paving the way towards the installation of inflammaging $[14,57]$. The cytomegalovirus (CMV) infection was considered one of the most important triggers of accumulation of senescent T cells [144, 145]. This consideration generated many studies to evaluate whether senescence of the immune cells could be considered detrimental or beneficial. Certainly, the accumulation of senescent cells has numerous maladaptive aspects [146, 147]; but, as many recent studies have shown, it also has adaptive aspects [148]. Finally, the exact percentage of the senescent/exhausted $\mathrm{T}$ cells at different ages and what role they may play physiologically is not clearly settled in this context. It may be that they (mainly exhausted T cells) are like the reserve in the army which can awaken when the well-trained $\mathrm{T}$ cells are not able to combat pathologies like cancer [149-151]. In view of the continuous production of immune cells, it seems likely that part of accumulated memory immune cells is not truly irreversibly senescent but rather exhausted, exhibiting reduced functional capabilities which can possibly be reversed when the circumstances may necessitate it [152].

With aging, not only phenotypic changes but also functional changes occur in the adaptive system, which may or may not be always related to the $T$ cell subpopulations but may be due directly to the immunobiography [38]. There are documented changes in the main signaling pathways in $\mathrm{T}$ cells, including the TCR, costimulatory receptors, and cytokine receptors, which lead to the decrease of cytokine production, proliferation, cytotoxicity, and differentiation [153-156]. Moreover, the metabolism of these cells is also affected because of the changes in the mTOR pathway either favoring the autophagy or the anabolic effects of its stimulation [157]. The changes from OxPhos in the resting state to aerobic glycolysis characterizing activated $\mathrm{T}$ cells are delayed and less intense in aging $\mathrm{T}$ cells $[158,159]$. These changes in the functioning may arise from the membrane changes with aging altering the immune synapse formation and consequently the cognate signaling pathways $[160,161]$. The changes either in the feedforward or feedback pathways are very complex - as the experimental results suggest - but together, we can say that they may decrease the efficiency of the $\mathrm{T}$ and $\mathrm{B}$ cell responses 
with age in certain circumstances which can really have detrimental consequences for the individual [162-164]. There are also new data that some pathways (precisely the JAK-STAT pathway [165]) in the resting $T$ cells are activated with age.

To summarize the immune changes in the continuity from the innate to the adaptive immune response, it can be concluded that the immune response in old individuals is complex and heterogenous and probably is more dependent on the type of challenge than from the age of the subjects $[166,167]$. Furthermore, many compensatory and redundant mechanisms are inbuilt to assure an adequate immune response even in the very elderly. Thus, there is an equilibrium between adaptation and maladaptation, and this balance may be disrupted depending on the type, the degree, and the acuteness of aggression (Fig. 1).

\section{Immunosuppressive mechanisms}

The performance of the immune system cannot be completely evaluated without discussing the role of the inbuilt immune suppressor mechanisms which may also be affected by age [168-170]. First, the role of Tregs is double; on the one hand, they should control the extent of the inflammation, and on the other hand, they should avoid the autoimmune processes arising continuously in the body and assure the attrition of the immune response once the danger has been eradicated [168, 171]. Given the central role of Treg cells in immune homeostasis, age-related loss of Treg function would be predicted to render the host susceptible to excessive immunity, encountered in elderly humans as a syndrome of chronic low-grade inflammation [172]. Conversely, age-dependent gain of Treg activity would expose the host to greater risk of immune failure, such as the rising risk of malignancies and infections in the aging population [171]. Emerging data suggest that some Treg populations, specifically naturally occurring Tregs (nTreg), seem to accumulate with advancing age, whereas inducible Tregs (iTreg) appear to be less available in the older host, though this is controversial [118]. Human studies assessing peripheral blood of aged versus young individuals seem to concur that the percentage of $\mathrm{CD} 4^{+}$Tregs is increased in older individuals $[173,174]$. All these data indicate that the $\mathrm{CD}^{+}$Treg compartment expands with age, relative to the total $\mathrm{CD}^{+}{ }^{+} \mathrm{T}$ cells. Human $\mathrm{CD} 4^{+} \mathrm{FOXP}^{+}$Tregs from older individuals show enhanced FOXP3 expression compared with Tregs from young individuals, while the remainder of their

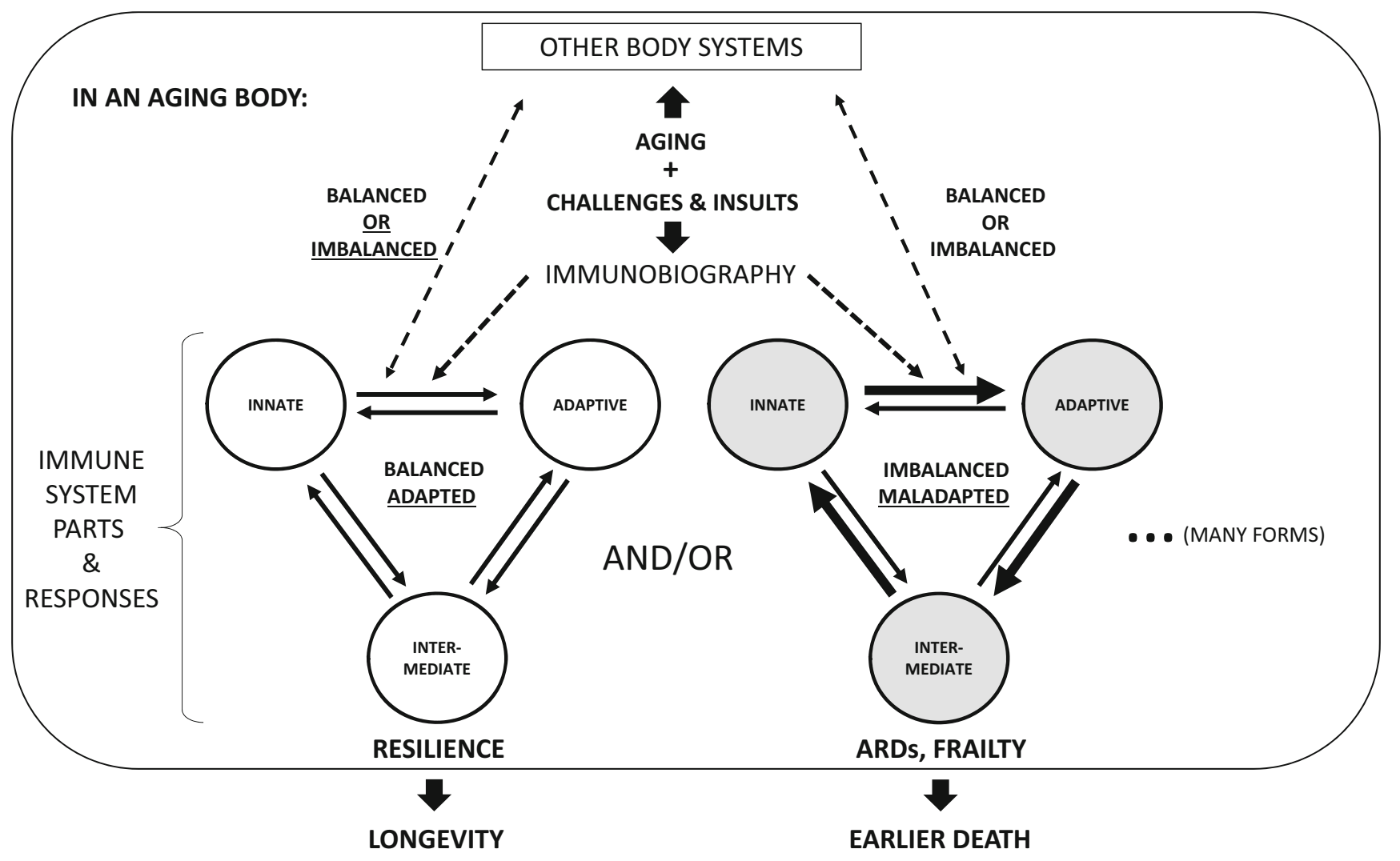

Fig. 1. The balance between the adaptive/maladaptive patterns of an individual's aging immune system. Adaptive and maladaptive immune changes can be found simultaneously in the same individual and in the same arms of the immune response (innate or adaptive). Concurrent (also balanced or imbalanced) changes in other body systems will affect the immune system. Complex integrated immunobiography over time will determine which state (balanced/adapted or imbalanced/maladapted) will predominate and towards which destiny (resilience and longevity, or aging-related diseases, frailty and earlier death) the organism will be pushed 
phenotypic makeup (GITR, CTLA-4, CD127 ${ }^{\text {low }}$ ) is unchanged [175]. The implication of this finding is that although Tregs retain most of their functional properties, which would be responsible for suppressing immune activation against infection and tumors, while in the meantime, they may fail to control autoimmune inflammation. However, autoimmune diseases are relatively rare in elderly [176]. Such an abnormality suggests that an apparent paradox is observed during aging as an aberrant inflammation coexists with immune hyporesponsiveness to infection, vaccination, and tumors [9]. Like $\mathrm{CD} 4^{+}$Tregs, the percentage of $\mathrm{CD} 8^{+} \mathrm{FOXP}^{+}$Tregs has been shown to be significantly increased in the blood of older individuals [177]. Given the critical role of Tregs in immune homeostasis, any decline in Treg competence would inevitably lead to a disbalance of protective and pathogenic immunity and would favor chronic, relentless, and possibly tissuedamaging inflammation [171]. In reality, as already discussed above, aging is indeed associated with a low-grade but clinically not manifest inflammation (inflammaging) which is not out of control. This indicates that the increased Treg number sufficiently control inflammaging, in contrast to what it is commonly stated. In contrast, increased numbers of Tregs could be considered detrimental in the suppression for the specific adaptive immune responses, mainly in infections and eventually in cancer [168]. It is of note that in cancer Tregs were demonstrated to be immunosuppressive directly in the tumor microenvironment [178]. It is also questionable whether their role in the specific immune response is detrimental or regulatory, as the age-related inflammatory diseases start at middle age and not in old age. The well-regulated Treg activity may also prevent a hyperreactivity of the immune system, as is seen in the present COVID-19 infection in a form of cytokine storm.

There is another major immunoregulatory/suppressor cell type, namely, myeloid derived suppressor cells (MDSCs) $[170,179]$. The MDSCs are specialized immunosuppressors which can control the functions of all other immune cells, thus preventing excessive inflammatory responses [180]. There is convincing evidence that the aging process increases the frequencies of circulating MDSCs in humans [181]. Verschoor et al. [182] revealed that the levels of the $\mathrm{CD} 11 \mathrm{~b}^{+} \mathrm{CD} 15^{+}$and granulocytic MDSCs were increased in the blood of community-dwelling seniors (61-76 years) and especially in frail elderly people (67-99 years). Furthermore, it was shown that the MDSCs induce the increase of Tregs [170, 183]. In this way, there is an immunosuppressive network which is created as individuals are aging as coined by Salminen et al. [184]. It seems that TGF- $\beta$, IL-10, and NO, secreted by MDSCs, are the major soluble mediators maintaining the functions of this age-related immunosuppressive network [185]. There is an abundant literature indicating that TGF- $\beta$ signaling suppresses the functions of $\mathrm{CD}^{+}{ }^{+}[186]$ and $\mathrm{CD} 8^{+}$ [187] T cells as well as DCs [188] and NK cells [189]. In particular, TGF- $\beta$ inhibits the signaling pathways of CD28 and mTOR kinase [190]. IL-10 also inhibits the CD28mediated signaling in T cells by activating SHP-1 tyrosine phosphatase-1 [191].

Together, the immunosuppressive network increase with aging may have several pathological consequences [184, 185], but however, in the spirit of immunobiography, this can also be considered an adaptation to decrease the lifelong activation process of the innate immune system (innate immune memory) but unfortunately in the meantime downregulate adaptive immune activation.

\section{Centenarians}

Among the elderly, the number of centenarians and semisupercentenarians is steadily increasing, especially in the blue zones [192]. There is a debate as to whether centenarians and semi-supercentenarians are the result of selection or whether they represent the way that humans should physiologically age, with others simply having risk factors that preclude them from attaining this age even if we consider their genetic specificities. Centenarians are a category of exceptionally aged individuals that succeed in preventing or delaying the onset of age-related disorders such as CV disease, type 2 diabetes mellitus (T2DM), Alzheimer's disease, or cancer [193, 194]. It is also well-known that these centenarians do not avoid major diseases but are able to counteract their deleterious effects, which most of the other elderly are not capable of. Probably the advantage that they have is what we could call the "adaptage," which during their immunobiography resulted in the development of resilience which could overcome the many dysfunctions and lead to a maintained functionality [192]. The centenarians have adapted their immune responses which maintain an adequate functionality and, in the meantime, control inflammaging [31,32, 195]. This means that they have an efficient anti-inflammaging machinery which may be constituted from immunosuppressive cells and soluble mediators like circulating gp130 to compensate for their increased IL-6 level [32]. In this context, Pawelec's group has shown a positive correlation between increased frequency of Tregs and survival in the elderly, which suggests the increasing importance of maintaining a balance between the adaptation and the maladaptation of immune responses and inflammation as we grew old [196].

One example of this adaptation/maladaptation is the microbiome largely influencing/shaping the functioning of all physiological systems, particularly that of the immune system in centenarians [193, 197-199]. Extreme longevity seems also to be associated with a unique shift of the gut microbiome characterized by enrichment in Akkermansia, Bifidobacterium, and Christensenellaceae [200]. On one hand, microbiota in centenarians show more diversity than 
in young old, resembling more that found in young subjects [201]. Here, certain aspects of the changes in centenarians and semi-supercentenarians are proinflammatory, such as the decline in the abundance of the putative butyrate producers like Faecalibacterium (phylum Firmicutes), while on the other hand within the Bacteroidetes phylum, Rikenellaceae (Alistipes) and Porphyromonaceae (Parabacteroides, Odoribacter, Porphyromonas), also butyrate producers, were found to be increased in all centenarians [201] with the concomitant decrease of Prevotella (phylum Bacteroidetes) richness, sustaining the changes in microbiota holding strong antiinflammatory activity $[202,203]$. Thus, the dysbiosis, proinflammatory change in microbiota composition in the oldest old, is compensated by the increase of anti-inflammatory bacteria which are metabolically more active than the former [204]. Thus, the microbiota of centenarians support both the increase in the inflammatory load found in the sera but also a compensatory mechanism which is maintaining a fine balance, nevertheless favoring longevity.

We should also mention that not all centenarians are made equal. A recent study by Tedone et al. [192] studied telomere length and telomerase activity in T cells from low- and highperforming centenarians. They identified several parameters that are different between high- and low-performing centenarians: (a) The amount of proliferation following in vitro stimulation is dramatically greater in high-performing centenarians compared with 67- to 83-year-old controls and lowperforming centenarians; (b) telomere length is greater in the high-performing centenarians; and (c) telomerase activity following stimulation is greater in the high-performing centenarians. In addition, this study has validated a number of genes whose expression was directly related to telomere length which may influence the risk and progression of multiple aging-associated conditions.

Together, centenarians have better resilience and biological reserves to effectively cope with multiple issues originated from their immunobiography. They can also better cope with inflammaging as they are able to mount a powerful antiinflammaging response neutralizing the overall presence of inflammatory processes $[32,205]$. It was clearly demonstrated in case of the semi-supercentenarians in whom the most powerful determinant of longevity was the presence of controlled inflammation [33]. They are the perfect example of hormesis and homeodynamic balance, as they have all the described supposed detrimental effect of aging on the immune system, but they have a powerful compensatory mechanism, a perfect demonstration of the "adaptage" concept of the immune changes.

\section{COVID-19}

The understanding of adaptation/maladaptation of the immune system with aging was never more relevant than during the COVID-19 pandemic. It is widely stated that the old individuals are more susceptible $[6,9,206,207]$. This should help us to better understand the immune changes with aging which may be detrimental and which may be beneficial. As mentioned, not all elderly who are infected will progress to the severe stage and will not die either [208-211]. The SARSCoV-2 infection is a two-step inducer of the immune response. At the beginning, a functional immune system could contain the infection even in elderly [212, 213]. An effective innate and adaptive immunity is required to try to advance the response until efficient antibody production begins. Most of the elderly can fight the infection but perhaps will not establish protective immunity with $\mathrm{Ab}$. In those where the immune system is less efficient, the virus will propagate, and a massive destruction of the tissues, especially those possessing abundant ACE2 receptors, will ensue [214, 215]. Damaged cells will induce massive inflammation via the stimulation of macrophages producing the cytokine storm. As the lung is the main acute target for SARS-CoV-2, it could be that the lung epithelial cells may also participate in the inflammatory mediators' production [216]. This is not far from resembling the pathomechanism of sepsis [217, 218].

It is debatable whether good health is an advantage or not for the course of SARS-CoV-2 infection, as the huge immune response during the second phase may be a strong disadvantage $[219,220]$. It is also of note that among the elderly who died in the hospitals, only $1 \%$ had comorbidities [221]. In the nursing homes, the situation is different as the old persons living in these institutions are not only comorbid but very ill; otherwise they would not be in these institutions [222-225]. In their cases, already the first step is deficient, so they die as in the case of influenza from the immunosuppressive effect of the virus and the following increased infection by bacteria or fungi $[226,227]$. These differences in the elderly reflect their heterogeneity and also the differences of the immune status in each individual.

\section{What would it take to move from the "damn-age" concept to the "adaptage" concept?}

First of all, biology of aging research should dissociate itself from what can be called ageism. The idea that young individuals are by definition in a better state is a cultural belief, not a biological fact [227]. Thus, perhaps not all data should be interpreted as detrimental, but considered from an evolutionary and immunobiographic perspective, including the concepts of balanced adaptation/maladaptation as the norm. It should also move from the "good versus bad" concept that biology does not recognize, as these are moral concepts. Furthermore, researchers should not derive unequivocal conclusions from mouse data applied to humans, as they do not 
always follow the same path. In fact, the majority of the immune system-related data refer to mouse data without sufficient warning about the profound difference between murine biology and human biology. These data are highly misleading and lead to many failures when applied to humans. One recent example is the failure of vaccination and use of monoclonal antibodies for treating Alzheimer's disease [228].

One of the most important criticisms of human studies is the heterogeneity of humans, which increases with age. This is absolutely true, but this is not a disadvantage but a wealth. This is the only way to unravel how the immune and other related physiological systems age. The immune system and physiology more generally are canonical examples of complex adaptive systems [229, 230], and it is well-known that linear, cause-and-effect models perform poorly for understanding such systems [231]; nonetheless, much of the research in these fields has applied methodology based on controlled experiments, which assume that results in a tightly controlled environment (e.g., lab mice) are easily extrapolatable, rather than methodologies that embrace heterogeneity and complexity. Undoubtedly, the latter are challenging, but they are also essential if we want to arrive at robust conclusions. This is more and more emphasized in research papers when they deal with aging. The one mentioned for centenarians is a bright example of this necessity if we want to understand what is occurring during aging [192]. Another example is a study published a few years ago, which has shown how to identify the drivers of the interindividual diversity of the human immune system, which is crucial to understand their consequences for immune-mediated diseases. By examining the transcriptional responses of 1000 individuals to various microbial challenges, they have shown that age and sex influence the expression of many immunerelated genes, but their effects were overall moderate, whereas genetic factors affect a smaller gene set but with a stronger effect. These results enable us to understand the regulatory role of interindividual variants in the pathogenesis of immune-related diseases and improve our understanding of the respective effects of age, sex, and genetics on immune response variation [166].

Furthermore, better understanding not only of the changes in the adaptive $T$ cell compartment but also in the innate compartment occurring with aging will help to better understand how the inflammaging concept may also have some adaptive characteristics and not only be considered the driver of agerelated diseases [14]. It is of paramount importance to assess the role of the trained immune memory in aging humans [38, 67]. Furthermore, this would help also to design better vaccines. This is demonstrated by the success of Shingrix a vaccine designed for elderly to prevent herpes zoster reactivation, which uses a special adjuvant to help boost the innate immune stimulation toward an effective adaptive immune response in 80 to $90 \%$ of old individuals [29]. This would perhaps end the misleading concept that elderly do not respond to vaccination. As we have already stated, this is not the fault of the immune changes with aging but the use of inadequate vaccines, such as in the case of the influenza vaccines, and in particular vaccines that were designed for the immune systems of younger individuals. The increased success of the quadrivalent vaccine is the proof that elderly can built efficient and protective responses [232-234].

Finally, the understanding of the holistic nature as well as the step by step progression of the immune system should lead not to the "single pill" intervention model but to the multimodal/multistep intervention model.

\section{Conclusion}

Aging is a natural process which ultimately results in death. However, the aging process should not be defined only by the perspective of death, which is inevitable. Concomitantly, it is often conceptualized that aging is the major underlying cause of all alterations occurring with aging and leading to agerelated diseases, forgetting that these disease processes started long before the beginning of old age. However, the aging process is very different for each individual, which means that aging is not occurring uniformly in every human being. This underlies the plasticity of the physiological functions' changes accompanying aging, including those of the immune system.

The immune system has evolved to protect us from aggressions and challenges. It is well established that its dysfunction can lead to pathologies in the elderly. However, not all elderly will suffer from these diseases: more and more are reaching a very old age, with centenarians and semi-supercentenarians having a relatively well-functioning immune system. So, the immune system during life is depending on its individual, unique immunobiography, consequently developing concomitantly adaptative and maladaptive aspects of its functioning. The balance between these functions will determine how the person will age (Fig. 1). It is possible that the effect of age may only be detrimental, as the most common paradigm is stating. However, a more positive and balanced consideration of the immune response with aging will permit us to intervene in a judicious manner. Still, many studies are needed to learn how to not intervene when it is not necessary and how to intervene in a multimodal/multistep way where it is needed. Better lifestyle, vaccines, and microbiome modulation will help to increase the adaptaging part of the immune system for a healthier life of old individuals.

Funding This work was supported by grants from the Canadian Institutes of Health Research (CIHR) (No. 106634), the Société des médecins de l'Université de Sherbrooke, and the Research Center on Aging of the CIUSSS-CHUS, Sherbrooke, by the Polish Ministry of Science and Higher Education statutory grant $02-0058 / 07 / 262$ to JMW and by Agency for Science Technology and Research (A*STAR) to AL. A.A.C. and T.F. are 
members of the Fonds de recherche du Québec-Santé (FRQ-S)-supported Centre de recherche sur le vieillissement, and A.A.C. is also member of the FRQ-S-supported Centre de recherche du CHUS.

\section{Compliance with ethical standards}

Conflict of interest The authors declare that they have no conflict of interest.

\section{References}

1. Epidemiology Working Group for NCIP Epidemic Response, Chinese Center for Disease Control and Prevention (2020) The epidemiological characteristics of an outbreak of 2019 novel coronavirus diseases (COVID-19) in China. Zhonghua Liu Xing Bing Xue Za Zhi 41(2):145-151

2. Team CC-R (2020) Severe outcomes among patients with coronavirus disease 2019 (COVID-19) - United States, February 12March 16, 2020. MMWR Morb Mortal Wkly Rep 69(12):343346

3. Wu Z, Mc Googan JM (2020) Characteristics of and important lessons from the coronavirus disease 2019 (COVID-19) outbreak in China: summary of a report of 72314 cases from the Chinese Center for Disease Control and Prevention. JAMA. 323(13): 1239-1242

4. Wilson N, Kvalsvig A, Barnard AT, Baker MG (2020) Casefatality risk estimates for COVID-19 calculated by using a lag time for fatality. Emerg Infect Dis 26(6):1339-1441

5. Murthy S, Gomersall CD, Fowler RA (2020) Care for critically Ill patients with COVID-19. JAMA 323(15):1499-1500 https://doi. org/10.1001/jama.2020.3633

6. Fülöp T, Dupuis G, Witkowski JM, Larbi A (2016) The role of immunosenescence in the development of age-related diseases. Rev Invest Clin. 68(2):84-91

7. Müller L, Di Benedetto S, Pawelec G (2019) The immune system and its dysregulation with aging. Subcell Biochem. 91:21-43

8. Weyand CM, Goronzy JJ (2016;13 Suppl) Aging of the immune system. mechanisms and therapeutic targets. Ann Am Thorac Soc 5(Suppl 5):S422-S428

9. Franceschi C, Bonafè M, Valensin S, Olivieri F, De Luca M, Ottaviani E, De Benedictis G (2000) Inflamm-aging. An evolutionary perspective on immunosenescence. Ann N Y Acad Sci. 908:244-254

10. Buettner D, Skemp S (2016) Blue zones: lessons from the world's longest lived. Am J Lifestyle Med. 10(5):318-321

11. Huang Y, Mark JG (2017) Identification of a blue zone in a typical Chinese longevity region. Int J Environ Res Public Health. 14(6): 571

12. Nikolich-Žugich J (2018) The twilight of immunity: emerging concepts in aging of the immune system. Nat Immunol. 19(1): $10-19$

13. Thomas R, Wang W, Su DM (2020) Contributions of age-related thymic involution to immunosenescence and inflammaging. Immun Ageing. 17:2

14. Fülöp T, Larbi A, Witkowski JM (2019) Human inflammaging. Gerontology. 65(5):495-504

15. Ventura MT, Casciaro M, Gangemi S, Buquicchio R (2017) Immunosenescence in aging: between immune cells depletion and cytokines up-regulation. Clin Mol Allergy. 15:21

16. Aiello A, Farzaneh F, Candore G, Caruso C, Davinelli S, Gambino CM, Ligotti ME, Zareian N, Accardi G (2019) Immunosenescence and its hallmarks: how to oppose aging strategically? A Review of Potential Options for Therapeutic Intervention. Front Immunol 10:2247

17. Oishi Y, Manabe I (2016) Macrophages in age-related chronic inflammatory diseases. NPJ Aging Mech Dis. 2:16018

18. Xu W, Larbi A (2017) Markers of T cell senescence in humans. Int J Mol Sci. 18(8):1742

19. Mishto M, Santoro A, Bellavista E, Bonafé M, Monti D, Franceschi C (2003) Immunoproteasomes and immunosenescence. Ageing Res Rev. 2(4):419-432

20. Pawelec G (2017) Does the human immune system ever really become "senescent"? F1000Res 6:F1000 Faculty Rev-1323

21. Franceschi C, Garagnani P, Vitale G, Capri M, Salvioli S (2017) Inflammaging and 'garb-aging'. Trends Endocrinol Metab. 28(3): 199-212

22. Franceschi C, Garagnani P, Parini P, Giuliani C, Santoro A (2018) Inflammaging: a new immune-metabolic viewpoint for agerelated diseases. Nat Rev Endocrinol. 14(10):576-590

23. Monti D, Ostan R, Borelli V, Castellani G, Franceschi C (2017) Inflammaging and human longevity in the omics era. Mech Ageing Dev 165(Pt B):129-138

24. Xu W, Larbi A (2018) Immunity and inflammation: from Jekyll to Hyde. Exp Gerontol. 107:98-101

25. Fulop T, Larbi A, Dupuis G, Le Page A, Frost EH, Cohen AA, Witkowski JM, Franceschi C (2018) Immunosenescence and inflamm-aging as two sides of the same coin: friends or foes? Front Immunol. 8:1960

26. Kennedy BK, Berger SL, Brunet A, Campisi J, Cuervo AM, Epel ES, Franceschi C, Lithgow GJ, Morimoto RI, Pessin JE, Rando TA, Richardson A, Schadt EE, Wyss-Coray T, Sierra F (2014) Geroscience: linking aging to chronic disease. Cell. 159(4):709713

27. Sierra F (2016) The emergence of geroscience as an interdisciplinary approach to the enhancement of health span and life span. Cold Spring Harb Perspect Med. 6(4):a025163

28. López-Otín C, Blasco MA, Partridge L, Serrano M, Kroemer G (2013) The hallmarks of aging. Cell. 153(6):1194-1217

29. Lal H, Cunningham AL, Godeaux O, Chlibek R, Diez-Domingo J, Hwang SJ, Levin MJ, McElhaney JE, Poder A, Puig-Barberà J, Vesikari T, Watanabe D, Weckx L, Zahaf T, Heineman TC, ZOE50 Study Group (2015) Efficacy of an adjuvanted herpes zoster subunit vaccine in older adults. N Engl J Med. 372(22):20872096

30. Schwarz TF, Volpe S, Catteau G, Chlibek R, David MP, Richardus JH, Lal H, Oostvogels L, Pauksens K, Ravault S, Rombo L, Sonder G, Smetana J, Heineman T, Bastidas A (2018) Persistence of immune response to an adjuvanted varicella-zoster virus subunit vaccine for up to year nine in older adults. Hum Vaccin Immunother. 14(6):1370-1377

31. Tsoupras A, Lordan R, Zabetakis I (2018) Inflammation, not cholesterol, is a cause of chronic disease. Nutrients. 10(5):604

32. Minciullo PL, Catalano A, Mandraffino G, Casciaro M, Crucitti A, Maltese G, Morabito N, Lasco A, Gangemi S, Basile G (2016) Inflammaging and anti-inflammaging: the role of cytokines in extreme longevity. Arch Immunol Ther Exp (Warsz). 64(2): $111-126$

33. Arai Y, Martin-Ruiz CM, Takayama M, Abe Y, Takebayashi T, Koyasu S, Suematsu M, Hirose N, von Zglinicki T (2015) Inflammation, but not telomere length, predicts successful ageing at extreme old age: a longitudinal study of semisupercentenarians. EBioMedicine. 2(10):1549-1558

34. Daste A, Domblides C, Gross-Goupil M, Chakiba C, Quivy A, Cochin V, de Mones E, Larmonier N, Soubeyran P, Ravaud A (2017) Immune checkpoint inhibitors and elderly people: A review. Eur J Cancer. 82:155-166

35. Pawelec G (2019) Does patient age influence anti-cancer immunity? Semin Immunopathol. 41(1):125-131 
36. Yan Y, Shin WI, Pang YX, Meng Y, Lai J, You C, Zhao H, Lester E, Wu T, Pang CH (2020) The first 75 days of novel coronavirus (SARS-CoV-2) outbreak: recent advances, prevention, and treatment. Int J Environ Res Public Health. 17(7):2323

37. Spezzani V, Piunno A, Iselin HU (2020) Benign COVID-19 in an immunocompromised cancer patient - the case of a married couple. Swiss Med Wkly. 150:w20246

38. Franceschi C, Salvioli S, Garagnani P, de Eguileor M, Monti D, Capri M (2017) Immunobiography and the heterogeneity of immune responses in the elderly: a focus on inflammaging and trained immunity. Front Immunol. 8:982

39. Ciabattini A, Nardini C, Santoro F, Garagnani P, Franceschi C, Medaglini D (2018) Vaccination in the elderly: the challenge of immune changes with aging. Semin Immunol. 40:83-94

40. Candore G, Caruso C, Colonna-Romano G (2010) Inflammation, genetic background and longevity. Biogerontology 11(5):565573

41. Pera A, Campos C, López N, Hassouneh F, Alonso C, Tarazona R, Solana R (2015) Immunosenescence: implications for response to infection and vaccination in older people. Maturitas. 82(1):50 55

42. Fukushima Y, Minato N, Hattori M (2018) The impact of senescence-associated $\mathrm{T}$ cells on immunosenescence and agerelated disorders. Inflamm Regen. 38:24

43. Fuentes E, Fuentes M, Alarcón M, Palomo I (2017) Immune system dysfunction in the elderly. An Acad Bras Cienc. 89(1):285299

44. Boraschi D, Italiani $\mathrm{P}$ (2014) Immunosenescence and vaccine failure in the elderly: strategies for improving response. Immunol Lett 162(1 Pt B):346-353

45. Lanna A, Gomes DC, Muller-Durovic B, McDonnell T, Escors D, Gilroy DW, Lee JH, Karin M, Akbar AN (2017) A sestrindependent Erk-Jnk-p38 MAPK activation complex inhibits immunity during aging. Nat Immunol. 18(3):354-363

46. Medzhitov R, Janeway CA Jr (1997) Innate immunity: impact on the adaptive immune response. Curr Opin Immunol. 9(1):4-9

47. Kennedy MA (2010) A brief review of the basics of immunology: the innate and adaptive response. Vet Clin North Am Small Anim Pract. 40(3):369-379

48. Robertson M (1998) Innate immunity. Curr Biol. 8(17):R595R597

49. Yatim KM, Lakkis FG (2015) A brief journey through the immune system. Clin J Am Soc Nephrol. 10(7):1274-1281

50. Tomar N, De RK (2014) A brief outline of the immune system. Methods Mol Biol. 1184:3-12

51. McComb S, Thiriot A, Akache B, Krishnan L, Stark F (2019) Introduction to the immune system. Methods Mol Biol. 2024:124

52. Parisi L, Gini E, Baci D, Tremolati M, Fanuli M, Bassani B, Farronato G, Bruno A, Mortara L (2018) Macrophage polarization in chronic inflammatory diseases: killers or builders? J Immunol Res 2018:8917804

53. Hato T, Dagher PC (2015) How the innate immune system senses trouble and causes trouble. Clin J Am Soc Nephrol. 10(8):14591469

54. Hansson GK, Hermansson A (2011) The immune system in atherosclerosis. Nat Immunol. 12(3):204-212

55. Coussens LM, Werb Z (2002) Inflammation and cancer. Nature 420(6917):860-867

56. Le Page A, Dupuis G, Frost EH, Larbi A, Pawelec G, Witkowski JM, Fulop T (2018) Role of the peripheral innate immune system in the development of Alzheimer's disease. Exp Gerontol. 107:59 66

57. Fulop T, Witkowski JM, Olivieri F, Larbi A (2018) The integration of inflammaging in age-related diseases. Semin Immunol. 40: $17-35$
58. Kleinnijenhuis J, Quintin J, Preijers F, Joosten LA, Ifrim DC, Saeed S, Jacobs C, van Loenhout J, de Jong D, Stunnenberg HG, Xavier RJ, van der Meer JW, van Crevel R, Netea MG (2012) Bacille Calmette-Guerin induces NOD2-dependent nonspecific protection from reinfection via epigenetic reprogramming of monocytes. Proc Natl Acad Sci U S A 109(43):17537-17542

59. Gourbal B, Pinaud S, Beckers GJM, Van Der Meer JWM, Conrath U, Netea MG (2018 May) Innate immune memory: an evolutionary perspective. Immunol Rev. 283(1):21-40

60. Netea MG, van der Meer JW (2017) Trained immunity: an ancient way of remembering. Cell Host Microbe 21(3):297-300

61. Töpfer E, Boraschi D, Italiani P (2015) Innate immune memory: the latest frontier of adjuvanticity. J Immunol Res. 2015:478408

62. Arts RJW, Moorlag SJCFM, Novakovic B, Li Y, Wang SY, Oosting M, Kumar V, Xavier RJ, Wijmenga C, Joosten LAB, Reusken CBEM, Benn CS, Aaby P, Koopmans MP, Stunnenberg HG, van Crevel R, Netea MG (2018) BCG vaccination protects against experimental viral infection in humans through the induction of cytokines associated with trained tmmunity. Cell Host Microbe 23(1):89-100.e5

63. Saeed S, Quintin J, Kerstens HH, Rao NA, Aghajanirefah A, Matarese F, Cheng SC, Ratter J, Berentsen K, van der Ent MA, Sharifi N, Janssen-Megens EM, Ter Huurne M, Mandoli A, van Schaik T, Ng A, Burden F, Downes K, Frontini M, Kumar V, Giamarellos-Bourboulis EJ, Ouwehand WH, van der Meer JW, Joosten LA, Wijmenga C, Martens JH, Xavier RJ, Logie C, Netea MG, Stunnenberg HG (2014) Epigenetic programming of monocyte-to-macrophage differentiation and trained innate immunity. Science 345(6204): 1251086

64. Cheng SC, Quintin J, Cramer RA, Shepardson KM, Saeed S, Kumar V, Giamarellos-Bourboulis EJ, Martens JH, Rao NA, Aghajanirefah A, Manjeri GR, Li Y, Ifrim DC, Arts RJ, van der Veer BM, Deen PM, Logie C, O'Neill LA, Willems P, van de Veerdonk FL, van der Meer JW, Ng A, Joosten LA, Wijmenga C, Stunnenberg HG, Xavier RJ, Netea MG (2014) mTOR- and HIF- $1 \alpha$-mediated aerobic glycolysis as metabolic basis for trained immunity. Science. 345(6204): 1250684

65. van der Heijden CDCC, Noz MP, Joosten LAB, Netea MG, Riksen NP, Keating ST (2018) Epigenetics and trained immunity. Antioxid Redox Signal. 29(11):1023-1040

66. Domínguez-Andrés J, Novakovic B, Li Y, Scicluna BP, Gresnigt MS, Arts RJW, Oosting M, Moorlag SJCFM, Groh LA, Zwaag J, Koch RM, Ter Horst R, Joosten LAB, Wijmenga C, Michelucci A, van der Poll T, Kox M, Pickkers P, Kumar V, Stunnenberg H, Netea MG (2019) The itaconate pathway is a central regulatory node linking innate immune tolerance and trained immunity. Cell Metab 29(1):211-220.e5

67. Fulop T, Dupuis G, Baehl S, Le Page A, Bourgade K, Frost E, Witkowski JM, Pawelec G, Larbi A, Cunnane S (2016) From inflamm-aging to immune-paralysis: a slippery slope during aging for immune-adaptation. Biogerontology. 17(1):147-157

68. Sapey E, Greenwood H, Walton G, Mann E, Love A, Aaronson N, Insall RH, Stockley RA, Lord JM (2014) Phosphoinositide 3kinase inhibition restores neutrophil accuracy in the elderly: toward targeted treatments for immunosenescence. Blood. 123(2): 239-248

69. Bandaranayake T, Shaw AC (2016) Host resistance and immune aging. Clin Geriatr Med. 32(3):415-432

70. Fulop T, Larbi A, Douziech N, Fortin C, Guérard KP, Lesur O, Khalil A, Dupuis G (2004) Signal transduction and functional changes in neutrophils with aging. Aging Cell. 3(4):217-226

71. Fortin CF, Larbi A, Lesur O, Douziech N, Fulop T Jr (2006) Impairment of SHP-1 down-regulation in the lipid rafts of human neutrophils under GM-CSF stimulation contributes to their agerelated, altered functions. J Leukoc Biol. 79(5):1061-1072 
72. Dilger RN, Johnson RW (2008) Aging, microglial cell priming, and the discordant central inflammatory response to signals from the peripheral immune system. J Leukoc Biol. 84(4):932-939

73. Spittau B (2017) Aging microglia-phenotypes, Functions and Implications for Age-Related Neurodegenerative Diseases. Front Aging Neurosci 9:194

74. Crooke SN, Ovsyannikova IG, Poland GA, Kennedy RB (2019) Immunosenescence: a systems-level overview of immune cell biology and strategies for improving vaccine responses. Exp Gerontol. 124:110632

75. Bonilla FA, Oettgen HC (2010) Adaptive immunity. J Allergy Clin Immunol. 125(2 Suppl 2):S33-S40

76. Artis D, Spits H (2015) The biology of innate lymphoid cells. Nature. 517(7534):293-301

77. Mazzurana L, Rao A, Van Acker A, Mjösberg J (2018) The roles for innate lymphoid cells in the human immune system. Semin Immunopathol. 40(4):407-419

78. Yudanin NA, Schmitz F, Flamar AL, Thome JJC, Tait Wojno E, Moeller JB, Schirmer M, Latorre IJ, Xavier RJ, Farber DL, Monticelli LA, Artis D (2019) Spatial and temporal mapping of human innate lymphoid cells reveals elements of tissue specificity. Immunity 50(2):505-519.e4

79. Nagasawa M, Spits H, Ros XR (2018) Innate lymphoid cells (ILCs): cytokine hubs regulating immunity and tissue homeostasis. Cold Spring Harb Perspect Biol. 10(12):a030304

80. Ebbo M, Crinier A, Vély F, Vivier E (2017) Innate lymphoid cells: major players in inflammatory diseases. Nat Rev Immunol. 17(11):665-678

81. Ardain A, Domingo-Gonzalez R, Das S, Kazer SW, Howard NC, Singh A, Ahmed M, Nhamoyebonde S, Rangel-Moreno J, Ogongo P, Lu L, Ramsuran D, de la Luz Garcia-Hernandez M, K Ulland T, Darby M, Park E, Karim F, Melocchi L, Madansein R, Dullabh KJ, Dunlap M, Marin-Agudelo N, Ebihara T, Ndung'u T, Kaushal D, Pym AS, Kolls JK, Steyn A, Zúñiga J, Horsnell W, Yokoyama WM, Shalek AK, Kløverpris HN, Colonna M, Leslie A, Khader SA (2019) Group 3 innate lymphoid cells mediate early protective immunity against tuberculosis. Nature 570(7762):528532

82. Ikeda A, Ogino T, Kayama H, Okuzaki D, Nishimura J, Fujino S, Miyoshi N, Takahashi H, Uemura M, Matsuda C, Yamamoto H, Takeda K, Mizushima T, Mori M, Doki Y (2020) Human NKp44+ group 3 innate lymphoid cells associate with tumorassociated tertiary lymphoid structures in colorectal cancer. Cancer Immunol Res 8(6):724-731

83. Kotas ME, Locksley RM (2018) Why innate lymphoid cells? Immunity. 48(6): 1081-1090

84. Mangan BA, Dunne MR, O'Reilly VP, Dunne PJ, Exley MA, O'Shea D, Scotet E, Hogan AE, Doherty DG (2013) CD1d restriction and Th1/Th2/Th17 cytokine secretion by human V $83 \mathrm{~T}$ cells. J Immunol Baltim Md 1950 191:30-34

85. Uldrich AP, Le Nours J, Pellicci DG, Gherardin NA, McPherson KG, Lim RT, Patel O, Beddoe T, Gras S, Rossjohn J et al (2013) CD1d-lipid antigen recognition by the $\gamma \delta$ TCR. Nat. Immunol. 14:1137-1145

86. Vasudev A, Ying CT, Ayyadhury S, Puan KJ, Andiappan AK, Nyunt MS, Shadan NB, Mustafa S, Low I, Rotzschke O, Fulop T, $\mathrm{Ng}$ TP, Larbi A (2014) $\gamma / \delta$ T cell subsets in human aging using the classical $\alpha / \beta$ T cell model. J Leukoc Biol. 96(4):647-655

87. Bhat J, Dubin S, Dananberg A, Quabius ES, Fritsch J, Dowds CM, Saxena A, Chitadze G, Lettau M, Kabelitz D (2019) Histone deacetylase inhibitor modulates NKG2D receptor expression and memory phenotype of human gamma/delta $\mathrm{T}$ cells upon interaction with tumor cells. Front Immunol. 10:569

88. Chitadze G, Lettau M, Luecke S, Wang T, Janssen O, Fürst D, Mytilineos J, Wesch D, Oberg HH, Held-Feindt J, Kabelitz D (2015) NKG2D- and T-cell receptor-dependent lysis of malignant glioma cell lines by human $\gamma \delta \mathrm{T}$ cells: Modulation by temozolomide and A disintegrin and metalloproteases 10 and 17 inhibitors. Oncoimmunology. 5(4):e1093276

89. Karunakaran MM, Herrmann T (2014) The V $\gamma 9 \mathrm{~V} \delta 2 \mathrm{~T}$ cell antigen receptor and butyrophilin-3 A1: models of interaction, the possibility of co-evolution, and the case of dendritic epidermal T cells. Front Immunol. 5:648

90. Kjer-Nielsen L, Corbett AJ, Chen Z, Liu L, Mak JY, Godfrey DI, Rossjohn J, Fairlie DP, McCluskey J, Eckle SB (2018) An overview on the identification of MAIT cell antigens. Immunol Cell Biol. 96(6):573-587

91. Xu W, Monaco G, Wong EH, Tan WLW, Kared H, Simoni Y, Tan SW, How WZY, Tan CTY, Lee BTK, Carbajo D, K G S, Low ICH, Mok EWH, Foo S, Lum J, Tey HL, Tan WP, Poidinger M, Newell E, Ng TP, Foo R, Akbar AN, Fülöp T, Larbi A (2019) Mapping of $\gamma / \delta \mathrm{T}$ cells reveals $\mathrm{V} \delta 2+\mathrm{T}$ cells resistance to senescence. EBioMedicine. 39:44-58

92. Tan CT, Wistuba-Hamprecht K, Xu W, Nyunt MS, Vasudev A, Lee BT, Pawelec G, Puan KJ, Rotzschke O, Ng TP, Larbi A (2016) $\mathrm{V} \delta 2+$ and $\alpha / \beta \mathrm{T}$ cells show divergent trajectories during human aging. Oncotarget. 7(29):44906-44918

93. Yang Q, Bhandoola A (2016) The development of adult innate lymphoid cells. Curr Opin Immunol. 39:114-120

94. Vivier E, Artis D, Colonna M, Diefenbach A, Di Santo JP, Eberl G, Koyasu S, Locksley RM, McKenzie ANJ, Mebius RE, Powrie F, Spits H (2018) Innate lymphoid cells: 10 years on. Cell. 174(5): 1054-1066

95. Fung ITH, Sankar P, Zhang Y, Robison LS, Zhao X, D'Souza SS, Salinero AE, Wang Y, Qian J, Kuentzel ML, Chittur SV, Temple S, Zuloaga KL, Yang Q (2020) Activation of group 2 innate lymphoid cells alleviates aging-associated cognitive decline. J Exp Med. 217(4):e20190915

96. Goronzy JJ, Weyand CM (2013) Understanding immunosenescence to improve responses to vaccines. Nat Immunol. 14(5):428-436

97. Hao Y, O'Neill P, Naradikian MS, Scholz JL, Cancro MP (2011) A B-cell subset uniquely responsive to innate stimuli accumulates in aged mice. Blood. 118(5):1294-1304

98. Ratliff M, Alter S, Frasca D, Blomberg BB (2013) Riley RL In senescence, age-associated $B$ cells secrete TNF $\alpha$ and inhibit survival of B-cell precursors. Aging Cell. 12(2):303-311

99. Rubtsov AV, Rubtsova K, Fischer A, Meehan RT, Gillis JZ, Kappler JW, Marrack P (2011) Toll-like receptor 7 (TLR7)-driven accumulation of a novel CD11 $\mathrm{c}^{+} \mathrm{B}$-cell population is important for the development of autoimmunity. Blood. 118(5):1305-1315

100. Rubtsova K, Rubtsov AV, Cancro MP, Marrack P (2015) Ageassociated B cells: a T-bet-dependent effector with roles in protective and pathogenic immunity. J Immunol. 195(5):1933-1937

101. Wong C, Goldstein DR (2013) Impact of aging on antigen presentation cell function of dendritic cells. Curr Opin Immunol. 25(4): 535-541

102. Zak DE, Tam VC, Aderem A (2014) Systems-level analysis of innate immunity. Annu Rev Immunol. 32:547-577

103. Solana R, Tarazona R, Gayoso I, Lesur O, Dupuis G, Fulop T (2012) Innate immunosenescence: effect of aging on cells and receptors of the innate immune system in humans. Semin Immunol. 24(5):331-341

104. Shaw AC, Joshi S, Greenwood H, Panda A, Lord JM (2010) Aging of the innate immune system. Curr Opin Immunol. 22(4): 507-513

105. Drew W, Wilson DV, Sapey E (2018) Inflammation and neutrophil immunosenescence in health and disease: Targeted treatments to improve clinical outcomes in the elderly. Exp Gerontol. 105: $70-77$

106. Clark HL, Banks R, Jones L, Hornick TR, Higgins PA, Burant CJ, Canaday DH (2012) Characterization of MHC-II antigen 
presentation by B cells and monocytes from older individuals. Clin Immunol. 144(2):172-177

107. Kajimura J, Lynch HE, Geyer S, French B, Yamaoka M, Shterev ID, Sempowski GD, Kyoizumi S, Yoshida K, Misumi M, Ohishi W, Hayashi T, Nakachi K, Kusunoki Y (2018) Radiation- and age-associated changes in peripheral blood dendritic cell populations among aging atomic bomb survivors in Japan. Radiat Res. 189(1):84-94

108. Banchereau J, Steinman RM (1998) Dendritic cells and the control of immunity. Nature. 392(6673):245-252

109. Sung SJ (2019) Monocyte-derived dendritic cells as antigenpresenting cells in T-cell proliferation and cytokine production. Methods Mol Biol. 2020:131-141

110. Satoh T, Akira S (2016) Toll-like receptor signaling and its inducible proteins. Microbiol Spectr 4(6)

111. Hemmi H, Akira S (2005) TLR signalling and the function of dendritic cells. Chem Immunol Allergy. 86:120-135

112. Shodell M, Siegal FP (2002) Circulating, interferon-producing plasmacytoid dendritic cells decline during human ageing. Scand J Immunol 56:518-521

113. Della Bella S, Bierti L, Presicce P, Arienti R, Valenti M, Saresella $\mathrm{M}$ et al (2007) Peripheral blood dendritic cells and monocytes are differently regulated in the elderly. Clin Immunol 122:220-228

114. Jing Y, Shaheen E, Drake RR, Chen N, Gravenstein S, Deng Y (2009) Aging is associated with a numerical and functional decline in plasmacytoid dendritic cells, whereas myeloid dendritic cells are relatively unaltered in human peripheral blood. Hum Immunol 70:777-784

115. Panda A, Qian F, Mohanty S, van Duin D, Newman FK, Zhang L et al (2010) Age-associated decrease in TLR function in primary human dendritic cells predicts influenza vaccine response. J Immunol 184:2518-2527

116. Agrawal A, Agrawal S, Gupta S (2007) Dendritic cells in human aging. Exp Gerontol 42:421-426

117. Agrawal A, Tay J, Ton S, Agrawal S, Gupta S (2009) Increased reactivity of dendritic cells from aged subjects to self-antigen, the human DNA. J Immunol 182:1138-1145

118. Witkowski JM, Gorgas G, Miller RA (1996) Reciprocal expression of P-glycoprotein and TAP1 accompanied by higher expression of MHC class I antigens in T cells of old mice. J Gerontol A Biol Sci Med Sci. 51(1):B76-B82

119. Assounga AG, Warner CM (2005 Winter) Memory lymphocytes of young and old C57BL/6 mice express high levels of class I major histocompatibility complex $(\mathrm{H}-2 \mathrm{~Kb})$ protein. Growth Dev Aging. 69(2):59-66

120. Herrero C, Sebastián C, Marqués L, Comalada M, Xaus J, Valledor AF, Lloberas J, Celada A (2002) Immunosenescence of macrophages: reduced MHC class II gene expression. Exp Gerontol. 37(2-3):389-394

121. Metcalf TU, Cubas RA, Ghneim K, Cartwright MJ, Grevenynghe JV, Richner JM, Olagnier DP, Wilkinson PA, Cameron MJ, Park BS, Hiscott JB, Diamond MS, Wertheimer AM, Nikolich-Zugich J, Haddad EK (2015) Global analyses revealed age-related alterations in innate immune responses after stimulation of pathogen recognition receptors. Aging Cell. 14(3):421-432

122. Larbi A, Fulop T (2014) From "truly naïve" to "exhausted senescent" T cells: when markers predict functionality. Cytometry A. 85(1):25-35

123. Alves AS, Bueno V (2019) Immunosenescence: participation of T lymphocytes and myeloid-derived suppressor cells in agingrelated immune response changes. Einstein (Sao Paulo) 17(2): eRB4733

124. Bektas A, Schurman SH, Sen R, Ferrucci L (2017) Human T cell immunosenescence and inflammation in aging. J Leukoc Biol. 102(4):977-988
125. Alberro A, Osorio-Querejeta I, Sepúlveda L, Fernández-Eulate G, Mateo-Abad M, Muñoz-Culla M, Carregal-Romero S, Matheu A, Vergara I, López de Munain A, Sáenz-Cuesta M, Otaegui D (2019) T cells and immune functions of plasma extracellular vesicles are differentially modulated from adults to centenarians. Aging (Albany NY) 11(22):10723-10741

126. Maue AC, Haynes L (2009) CD4+ T cells and immunosenescence-a mini-review. Gerontology. 55(5):491495

127. Qi Q, Liu Y, Cheng Y, Glanville J, Zhang D, Lee JY, Olshen RA, Weyand CM, Boyd SD, Goronzy JJ (2014) Diversity and clonal selection in the human T-cell repertoire. Proc Natl Acad Sci U S A. 111(36):13139-13144

128. Britanova OV, Putintseva EV, Shugay M, Merzlyak EM, Turchaninova MA, Staroverov DB, Bolotin DA, Lukyanov S, Bogdanova EA, Mamedov IZ, Lebedev YB, Chudakov DM (2014) Age-related decrease in TCR repertoire diversity measured with deep and normalized sequence profiling. J Immunol. 192(6): 2689-2698

129. Hussain T, Quinn KM (2019) Similar but different: virtual memory CD8 T cells as a memory-like cell population. Immunol Cell Biol. 97(7):675-684

130. Davenport B, Eberlein J, van der Heide V, Jhun K, Nguyen TT, Victorino F, Trotta A, Chipuk J, Yi Z, Zhang W, Clambey ET, Scott DK, Homann D (2019) Aging of antiviral CD8(+) memory $\mathrm{T}$ cells fosters increased survival, metabolic adaptations, and lymphoid tissue homing. J Immunol. 202(2):460-475

131. Kim C, Hu B, Jadhav RR, Jin J, Zhang H, Cavanagh MM, Akondy RS, Ahmed R, Weyand CM, Goronzy JJ (2018) Activation of miR-21-regulated pathways in immune aging selects against signatures characteristic of memory $\mathrm{T}$ cells. Cell Rep 25(8):2148-2162.e5

132. Mayya V, Judokusumo E, Abu-Shah E, Neiswanger W, Sachar C, Depoil D, Kam LC, Dustin ML (2019) Cutting edge: synapse propensity of human memory CD8 T cells confers competitive advantage over naive counterparts. J Immunol. 203(3):601-606

133. Goronzy JJ, Weyand CM (2017) Successful and maladaptive T Cell Aging. Immunity. 46(3):364-378

134. Koff WC, Williams MA (2020) Covid-19 and immunity in aging populations - a new research agenda. N Engl J Med 383(9):804-805

135. Herndler-Brandstetter D, Landgraf K, Tzankov A, Jenewein B, Brunauer R, Laschober GT, Parson W, Kloss F, Gassner R, Lepperdinger G, Grubeck-Loebenstein B (2012) The impact of aging on memory $\mathrm{T}$ cell phenotype and function in the human bone marrow. J Leukoc Biol. 91(2):197-205

136. Wertheimer AM, Bennett MS, Park B, Uhrlaub JL, Martinez C, Pulko V, Currier NL, Nikolich-Žugich D, Kaye J, NikolichŽugich J (2014) Aging and cytomegalovirus infection differentially and jointly affect distinct circulating $\mathrm{T}$ cell subsets in humans. $\mathrm{J}$ Immunol. 192(5):2143-2155

137. Akbar AN, Fletcher JM (2005) Memory T cell homeostasis and senescence during aging. Curr Opin Immunol. 17(5):480-485

138. Henson SM, Akbar AN (2010) Memory T-cell homeostasis and senescence during aging. Adv Exp Med Biol. 684:189-197

139. Chou JP, Effros RB (2013) T cell replicative senescence in human aging. Curr Pharm Des. 19(9):1680-1698

140. Akbar AN, Henson SM, Lanna A (2016) Senescence of T lymphocytes: implications for enhancing human immunity. Trends Immunol. 37(12):866-876

141. Callender LA, Carroll EC, Bober EA, Henson SM (2018) Divergent mechanisms of metabolic dysfunction drive fibroblast and T-cell senescence. Ageing Res Rev. 47:24-30

142. Callender LA, Carroll EC, Beal RWJ, Chambers ES, Nourshargh S, Akbar AN, Henson SM (2018) Human CD8(+) EMRA T cells display a senescence-associated secretory phenotype regulated by p38 MAPK. Aging Cell. 17(1):e12675 
143. Sagiv A, Krizhanovsky V (2013) Immunosurveillance of senescent cells: the bright side of the senescence program. Biogerontology. 14(6):617-628

144. Jergović M, Contreras NA, Nikolich-Žugich J (2019) Impact of CMV upon immune aging: facts and fiction. Med Microbiol Immunol. 208(3-4):263-269

145. Spyridopoulos I, Martin-Ruiz C, Hilkens C, Yadegarfar ME, Isaacs J, Jagger C, Kirkwood T, von Zglinicki T (2016) CMV seropositivity and T-cell senescence predict increased cardiovascular mortality in octogenarians: results from the Newcastle 85+ study. Aging Cell. 15(2):389-392

146. Weinstein BS, Ciszek D (2002) The reserve-capacity hypothesis: evolutionary origins and modern implications of the trade-off between tumor-suppression and tissue-repair. Exp Gerontol. 37(5): 615-627

147. Rea IM, Gibson DS, McGilligan V, McNerlan SE, Alexander HD, Ross OA (2018) Age and age-related diseases: role of inflammation triggers and cytokines. Front Immunol. 9:586

148. Schmeer C, Kretz A, Wengerodt D, Stojiljkovic M, Witte OW (2019) Dissecting aging and senescence-current concepts and open lessons. Cells. 8(11):1446

149. Blank CU, Haining WN, Held W, Hogan PG, Kallies A, Lugli E, Lynn RC, Philip M, Rao A, Restifo NP, Schietinger A, Schumacher TN, Schwartzberg PL, Sharpe AH, Speiser DE, Wherry EJ, Youngblood BA, Zehn D (2019) Defining 'T cell exhaustion'. Nat Rev Immunol. 19(11):665-674

150. Pauken KE, Wherry EJ (2015) Overcoming T cell exhaustion in infection and cancer. Trends Immunol. 36(4):265-276

151. Wherry EJ, Kurachi M (2015) Molecular and cellular insights into T cell exhaustion. Nat Rev Immunol. 15(8):486-499

152. Pawelec G (2019) Is there a positive side to T cell exhaustion? Front Immunol. 10:111

153. Le Page A, Dupuis G, Larbi A, Witkowski JM, Fülöp T (2018) Signal transduction changes in CD4(+) and CD8(+) T cell subpopulations with aging. Exp Gerontol. 105:128-139

154. Goronzy JJ, Li G, Yu M, Weyand CM (2012) Signaling pathways in aged $\mathrm{T}$ cells - a reflection of $\mathrm{T}$ cell differentiation, cell senescence and host environment. Semin Immunol. 24(5):365-372

155. Gupta $S$ (1989) Membrane signal transduction in T cells in aging humans. Ann N Y Acad Sci. 568:277-282

156. Fulop T, Le Page A, Fortin C, Witkowski JM, Dupuis G, Larbi A (2014) Cellular signaling in the aging immune system. Curr Opin Immunol. 29:105-111

157. Bartlett AH, Liang JW, Sandoval-Sierra JV, Fowke JH, Simonsick EM, Johnson KC, Mozhui K (2019) Longitudinal study of leukocyte DNA methylation and biomarkers for cancer risk in older adults. Biomark Res. 7:10

158. Torrão RC, Bennett SJ, Brown JE, Griffiths HR (2014) Does metabolic reprogramming underpin age-associated changes in $\mathrm{T}$ cell phenotype and function? Free Radic Biol Med. Jun 71:26-35

159. Yanes RE, Zhang H, Shen Y, Weyand CM, Goronzy JJ (2019) Metabolic reprogramming in memory CD4 T cell responses of old adults. Clin Immunol. 207:58-67

160. Marko MG, Ahmed T, Bunnell SC, Wu D, Chung H, Huber BT, Meydani SN (2007) Age-associated decline in effective immune synapse formation of CD4(+) T cells is reversed by vitamin $\mathrm{E}$ supplementation. J Immunol. 178(3):1443-1449

161. Fulop T, Le Page A, Garneau H, Azimi N, Baehl S, Dupuis G, Pawelec G, Larbi A (2012) Aging, immunosenescence and membrane rafts: the lipid connection. Longev Healthspan. 1:6

162. Yu M, Li G, Lee WW, Yuan M, Cui D, Weyand CM, Goronzy JJ (2012) Signal inhibition by the dual-specific phosphatase $4 \mathrm{im}$ pairs T cell-dependent B-cell responses with age. Proc Natl Acad Sci U S A. 109(15):E879-E888

163. Li G, Yu M, Lee W-W, Tsang M, Krishnan E, Weyand CM, Jörg J, Goronzy JJ (2012) Decline in miR-181a expression with age impairs T cell receptor sensitivity by increasing DUSP6 activity. Nat Med. 18(10):1518-1524

164. Le Page A, Fortin C, Garneau H, Allard N, Tsvetkova K, Tan CT, Larbi A, Dupuis G, Fülöp T (2014) Downregulation of inhibitory SRC homology 2 domain-containing phosphatase-1 (SHP-1) leads to recovery of $\mathrm{T}$ cell responses in elderly. Cell Commun Signal. 12:2

165. Shen-Orr SS, Furman D, Kidd BA, Hadad F, Lovelace P, Huang Y-W, Rosenberg-Hasson Y, Mackey S, Gomari Grisar FA, Pickman Y, Maecker HT, Chien Y-H, Dekker CL, Wu JC, Butte AJ, Davis MM (2016) Defective signaling in the JAK-STAT pathway tracks with chronic inflammation and cardiovascular risk in aging humans. Cell Syst 3(4):374-384.e4. https://doi.org/10.1016/ j.cels.2016.09.009 Epub 2016 Oct 13.

166. Piasecka B, Duffy D, Urrutia A, Quach H, Patin E, Posseme C, Bergstedt J, Charbit B, Rouilly V, MacPherson CR, Hasan M, Albaud B, Gentien D, Fellay J, Albert ML, Quintana-Murci L, Milieu Intérieur Consortium (2018) Distinctive roles of age, sex, and genetics in shaping transcriptional variation of human immune responses to microbial challenges. Proc Natl Acad Sci U S A. 115(3):E488-E497

167. Ahadi S, Zhou W, Schüssler-Fiorenza Rose SM, Sailani MR, Contrepois K, Avina M, Ashland M, Brunet A, Snyder M (2020) Personal aging markers and ageotypes revealed by deep longitudinal profiling. Nat Med. 26(1):83-90

168. Jagger A, Shimojima Y, Goronzy JJ, Weyand CM (2014) Regulatory $\mathrm{T}$ cells and the immune aging process: a mini-review. Gerontology. 60(2):130-137

169. Wang L, Xie Y, Zhu LJ, Chang TT, Mao YQ, Li J (2010) An association between immunosenescence and CD4(+)CD25(+) regulatory T cells: a systematic review. Biomed Environ Sci. 23(4):327-332

170. Salminen A, Kaarniranta K, Kauppinen A (2019) Immunosenescence: the potential role of myeloid-derived suppressor cells (MDSC) in age-related immune deficiency. Cell Mol Life Sci. 76(10):1901-1918

171. Raynor J, Lages CS, Shehata H, Hildeman DA, Chougnet CA (2012) Homeostasis and function of regulatory T cells in aging. Curr Opin Immunol. 24(4):482-487

172. Goronzy JJ, Weyand CM (2012) Immune aging and autoimmunity. Cell Mol Life Sci. 69(10):1615-1623

173. Lages CS, Suffia I, Velilla PA, Huang B, Warshaw G, Hildeman DA, Belkaid Y, Chougnet C (2008) Functional regulatory T cells accumulate in aged hosts and promote chronic infectious disease reactivation. J Immunol. 181(3):1835-1848

174. Gottenberg JE, Lavie F, Abbed K, Gasnault J, Le Nevot E, Delfraissy JF, Taoufik Y, Mariette X (2005) CD4 CD25high regulatory $\mathrm{T}$ cells are not impaired in patients with primary Sjögren's syndrome. J Autoimmun. 24(3):235-242

175. Gregg R, Smith CM, Clark FJ, Dunnion D, Khan N, Chakraverty R, Nayak L, Moss PA (2005) The number of human peripheral blood CD4+ CD25high regulatory T cells increases with age. Clin Exp Immunol. 140(3):540-546

176. Prelog M (2006) Aging of the immune system: a risk factor for autoimmunity? Autoimmun Rev. 5(2):136-139

177. Simone R, Zicca A, Saverino D (2008) The frequency of regulatory CD3+CD8+CD28- CD25+ T lymphocytes in human peripheral blood increases with age. J Leukoc Biol. 84(6):1454-1461

178. Tanchot C, Terme M, Pere H, Tran T, Benhamouda N, Strioga M, Banissi C, Galluzzi L, Kroemer G, Tartour E (2013) Tumorinfiltrating regulatory T cells: phenotype, role, mechanism of expansion in situ and clinical significance. Cancer Microenviron. 6(2):147-157

179. Gabrilovich DI, Nagaraj S (2009) Myeloid-derived suppressor cells as regulators of the immune system. Nat Rev Immunol. 9(3):162-174. https://doi.org/10.1038/nri2506 
180. Motallebnezhad M, Jadidi-Niaragh F, Qamsari ES, Bagheri S, Gharibi T, Yousefi M (2016) The immunobiology of myeloidderived suppressor cells in cancer. Tumour Biol. 37(2):13871406. https://doi.org/10.1007/s13277-015-4477-9 Epub 2015 Nov 26

181. Alves AS, Ishimura ME, Duarte YAO, Bueno V (2018) Parameters of the immune system and vitamin D levels in old individuals. Front Immunol. 9:1122

182. Verschoor CP, Johnstone J, Millar J, Dorrington MG, Habibagahi M, Lelic A, Loeb M, Bramson JL, Bowdish DM (2013) Blood CD33(+)HLA-DR(-) myeloid-derived suppressor cells are increased with age and a history of cancer. J Leukoc Biol. 93(4): 633-637

183. Yang T, Li J, Li R, Yang C, Zhang W, Qiu Y, Yang C, Rong R (2019) Correlation between MDSC and immune tolerance in transplantation: cytokines, pathways and cell-cell interaction. Curr Gene Ther. 19(2):81-92

184. Salminen A, Kaarniranta K, Kauppinen A (2020) ER stress activates immunosuppressive network: implications for aging and Alzheimer's disease. J Mol Med (Berl). 98(5):633-650

185. Salminen A (2020) Activation of immunosuppressive network in the aging process. Ageing Res Rev. 57:100998

186. Delisle JS, Giroux M, Boucher G, Landry JR, Hardy MP, Lemieux S, Jones RG, Wilhelm BT, Perreault C (2013) The TGF- $\beta$-Smad3 pathway inhibits CD28-dependent cell growth and proliferation of CD4 T cells. Genes Immun 14:115-126

187. Tinoco R, Alcalde V, Yang Y, Sauer K, Zuniga EI (2009) Cellintrinsic transforming growth factor- $\beta$ signaling mediates virusspecific $\mathrm{CD} 8+\mathrm{T}$ cell deletion and viral persistence in vivo. Immunity $31: 145-157$

188. Esebanmen GE, Langridge WHR (2017) The role of TGF- $\beta$ signaling in dendritic cell tolerance. Immunol Res 65:987-994

189. Zaiatz-Bittencourt V, Finlay DK, Gardiner CM (2018) Canonical TGF- $\beta$ signaling pathway represses human NK cell metabolism. J Immunol 200:3934-3941

190. Viel S, Marçais A, Guimaraes FS, Loftus R, Rabilloud J, Grau M, Degouve S, Djebali S, Sanlaville A, Charrier E, Bienvenu J, Marie JC, Caux C, Marvel J, Town L, Huntington ND, Bartholin L, Finlay D, Smyth MJ, Walzer T (2016) TGF- $\beta$ inhibits the activation and functions of NK cells by repressing the mTOR pathway. Sci Signal 9(415):ra19

191. Taylor A, Akdis M, Joss A, Akkoc T, Wenig R, Colonna M, Daigle I, Flory E, Blaser K, Akdis CA (2007) IL-10 inhibits CD28 and ICOS costimulations of T cells via src homology 2 domain-containing protein tyrosine phosphatase 1. J Allergy Clin Immunol 120:76-83

192. Tedone E, Huang E, O'Hara R, Batten K, Ludlow AT, Lai TP, Arosio B, Mari D, Wright WE, Shay JW (2019) Telomere length and telomerase activity in $\mathrm{T}$ cells are biomarkers of highperforming centenarians. Aging Cell. 18(1):e12859

193. Biagi E, Rampelli S, Turroni S, Quercia S, Candela M, Brigidi P (2017) The gut microbiota of centenarians: Signatures of longevity in the gut microbiota profile. Mech Ageing Dev 165(Pt B):180184

194. Santoro A, Ostan R, Candela M, Biagi E, Brigidi P, Capri M, Franceschi C (2018) Gut microbiota changes in the extreme decades of human life: a focus on centenarians. Cell Mol Life Sci. 75(1):129-148

195. Sotgia S, Zinellu A, Mangoni AA, Serra R, Pintus G, Caruso C, Deiana L, Carru C (2017) Cellular immune activation in Sardinian middle-aged, older adults and centenarians. Exp Gerontol. 99: 133-137

196. Derhovanessian E, Chen S, Maier AB, Hähnel K, de Craen AJ, Roelofs H, Westendorp R, Pawelec G (2015) CCR4+ regulatory T cells accumulate in the very elderly and correlate with superior 8 year survival. J Gerontol A Biol Sci Med Sci. 70(8):917-923
197. Ganal-Vonarburg SC, Duerr CU (2020) The interaction of intestinal microbiota and innate lymphoid cells in health and disease throughout life. Immunology. 159(1):39-51

198. Mangiola F, Nicoletti A, Gasbarrini A, Ponziani FR (2018) Gut microbiota and aging. Eur Rev Med Pharmacol Sci. 22(21):7404 7413

199. Biagi E, Nylund L, Candela M, Ostan R, Bucci L, Pini E, Nikkïla J, Monti D, Satokari R, Franceschi C, Brigidi P, De Vos W (2010) Through ageing, and beyond: gut microbiota and inflammatory status in seniors and centenarians. PLoS One. 5(5):e10667

200. Kim BS, Choi CW, Shin H, Jin SP, Bae JS, Han M, Seo EY, Chun J, Chung JH (2019) Comparison of the gut microbiota of centenarians in longevity villages of South Korea with those of other age groups. J. Microbiol. Biotechnol. 29:429-440

201. Tuikhar N, Keisam S, Labala RK, Ramakrishnan Imrat P, Arunkumar MC, Ahmed G, Biagi E, Jeyaram K (2019) Comparative analysis of the gut microbiota in centenarians and young adults shows a common signature across genotypically non-related populations. Mech. Ageing Dev. 179:23-35

202. Rakoff-Nahoum S, Paglino J, Eslami-Varzaneh F, Edberg S, Medzhitov R (2014) Recognition of commensal microflora by toll-like receptors is required for intestinal homeostasis. Cell 118:229-241

203. Kong F, Hua Y, Zeng B, Ning R, Li Y, Zhao J (2016) Gut microbiota signatures of longevity. Curr. Biol. 26:R832-R833

204. C toi AF, Corina A, Katsiki N, Vodnar DC, Andreicut AD, Stoian AP, Rizzo M, Pérez-Martínez P (1866) Gut microbiota and agingA focus on centenarians. Biochim Biophys Acta Mol Basis Dis. 2020 Jul 1(7): 165765

205. Franceschi C, Capri M, Monti D, Giunta S, Olivieri F, Sevini F, Panourgia MP, Invidia L, Celani L, Scurti M, Cevenini E, Castellani GC, Salvioli S (2007) Inflammaging and antiinflammaging: a systemic perspective on aging and longevity emerged from studies in humans. Mech Ageing Dev. 128(1):92105

206. Bonafè M, Prattichizzo F, Giuliani A, Storci G, Sabbatinelli S, Olivieri F. Inflamm-aging: why older men are the most susceptible to SARS-Cov-2 complicated outcomes. reprints (www.preprints. org). https://doi.org/10.20944/preprints202004.0143.v1.

207. Nikolich-Zugich J, Knox KS, Rios CT, Natt B, Bhattacharya D, Fain MJ (2020) SARS-CoV-2 and COVID-19 in older adults: what we may expect regarding pathogenesis, immune responses, and outcomes. Geroscience. https://doi.org/10.1007/s11357-02000186-0

208. Guan WJ, Ni ZY, Hu Y, Liang WH, Ou CQ, He JX, Liu L, Shan H, Lei CL, Hui DSC, Du B, Li LJ, Zeng G, Yuen KY, Chen RC, Tang CL, Wang T, Chen PY, Xiang J, Li SY, Wang JL, Liang ZJ, Peng YX, Wei L, Liu Y, Hu YH, Peng P, Wang JM, Liu JY, Chen Z, Li G, Zheng ZJ, Qiu SQ, Luo J, Ye CJ, Zhu SY, Zhong NS; China medical treatment expert group for Covid-19. Clinical Characteristics of Coronavirus Disease 2019 in China. N Engl J Med. 2020;382(18):1708-1720.

209. Zhou F, Yu T, Du R, Fan G, Liu Y, Liu Z, Xiang J, Wang Y, Song B, Gu X, Guan L, Wei Y, Li H, Wu X, Xu J, Tu S, Zhang Y, Chen H, Cao B (2020) Clinical course and risk factors for mortality of adult inpatients with COVID-19 in Wuhan, China: a retrospective cohort study. Lancet. 395(10229):1054-1062

210. Xie J, Tong Z, Guan X, Du B, Qiu H (2020) Clinical characteristics of patients who died of coronavirus disease 2019 in China. JAMA Netw Open 3(4):e205619. https://doi.org/10.1001/ jamanetworkopen.2020.5619

211. Li X, Xu S, Yu M, Wang K, Tao Y, Zhou Y, Shi J, Zhou M, Wu B, Yang Z, Zhang C, Yue J, Zhang Z, Renz H, Liu X, Xie J, Xie M, Zhao J (2020) Risk factors for severity and mortality in adult COVID-19 inpatients in Wuhan. J Allergy Clin Immunol S00916749(20):30495-4 
212. Vardhana SA, Wolchok JD (2020 Jun 1) The many faces of the anti-COVID immune response. J Exp Med. 217(6): e20200678

213. Blanco-Melo D, Nilsson-Payant BE, Liu W-C, Uhl S, Hoagland D, Møller R, Jordan TX, Oishi K, Panis M, Sachs D, Wang TT, Schwartz RE, Lim JK, Albrecht RA, Benjamin R tenOever (2020) Imbalanced host response to SARS-CoV-2 drives development of COVID-19. Cell 181(5):1036-1045.e9. https://doi.org/10.1016/j. cell.2020.04.026

214. Cheng H, Wang Y, Wang GQ (2020) Organ-protective effect of angiotensin-converting enzyme 2 and its effect on the prognosis of COVID-19. J Med Virol 92(7):726-730

215. Sriram K, Insel PA (2020) A hypothesis for pathobiology and treatment of COVID-19: the centrality of ACE1/ACE2 imbalance. Br J Pharmacol. https://doi.org/10.1111/bph.15082

216. Astuti I, Ysrafil (2020) Severe acute respiratory syndrome coronavirus 2 (SARS-CoV-2): an overview of viral structure and host response. Diabetes Metab Syndr. 14(4):407-412

217. Qiu Y, Tu GW, Ju MJ, Yang C, Luo Z (2019) The immune system regulation in sepsis: from innate to adaptive. Curr Protein Pept Sci. 20(8):799-816

218. Martín S, Pérez A, Aldecoa C (2017) Sepsis and immunosenescence in the elderly patient: a review. Front Med (Lausanne) 4:20

219. Azkur AK, Akdis M, Azkur D, Sokolowska M, van de Veen W, Brüggen MC, O'Mahony L, Gao Y, Nadeau K, Akdis CA (2020) Immune response to SARS-CoV-2 and mechanisms of immunopathological changes in COVID-19. Allergy 75(7):1564-1581

220. Matricardi PM, Dal Negro RW, Nisini R (2020) The first, holistic immunological model of COVID-19: implications for prevention, diagnosis, and public health measures. Pediatr Allergy Immunol. https://doi.org/10.1111/pai.13271

221. Saghazadeh A, Rezaei N (2020) Immune-epidemiological parameters of the novel coronavirus - a perspective. Expert Rev Clin Immunol 0(0):1-6
222. Kunz R, Minder M (2020) COVID-19 pandemic: palliative care for elderly and frail patients at home and in residential and nursing homes. Swiss Med Wkly 150:w20235

223. Morley JE, Vellas B (2020) Editorial: COVID-19 and older adults. J Nutr Health Aging 24(4):364-365

224. Gardner W, States D, Bagley N (2020) The coronavirus and the risks to the elderly in long-term care. J Aging Soc Policy. 3:1-6

225. Shahid Z, Kalayanamitra R, McClafferty B, Kepko D, Ramgobin D, Patel R, Aggarwal CS, Vunnam R, Sahu N, Bhatt D, Jones K, Golamari R, Jain R (2020) COVID-19 and older adults: what we know. J Am Geriatr Soc 68(5):926-929

226. Vanderbeke L, Spriet I, Breynaert C, Rijnders BJA, Verweij PE, Wauters J (2018) Invasive pulmonary aspergillosis complicating severe influenza: epidemiology, diagnosis and treatment. Curr Opin Infect Dis 31(6):471-480

227. Cohen AA, Levasseur M, Raina P, Fried LP, Fülöp T (2019) Is aging biology ageist? J Gerontol A Biol Sci Med Sci glz190

228. van Dyck CH (2018) Anti-amyloid- $\beta$ monoclonal antibodies for Alzheimer's disease: pitfalls and promise. Biol Psychiatry 83(4): 311-319

229. Davis MM, Tato CM, Furman D (2017) Systems immunology: just getting started. Nat Immunol 18(7):725

230. Lansing JS (2003) Complex adaptive systems. Ann Rev Anthropol 32(1):183-204

231. Cohen AA (2016) Complex systems dynamics in aging: new evidence, continuing questions. Biogerontology 17(1):205-220

232. Wagner A, Weinberger B (2020) Vaccines to prevent infectious diseases in the older population: immunological challenges and future perspectives. Front Immunol 11:717

233. Iwasaki A, Medzhitov R (2015) Control of adaptive immunity by the innate immune system. Nat Immunol 16(4):343-353

234. Rynda-Apple A, Robinson KM, Alcorn JF (2015) Influenza and bacterial superinfection: illuminating the immunologic mechanisms of disease. Infect Immun 83(10):3764-3770

Publisher's note Springer Nature remains neutral with regard to jurisdictional claims in published maps and institutional affiliations. 